\title{
Law and Justice among the Socratics: Contexts for Plato's Republic
}

\author{
Phillip Sidney Horky \\ Associate Professor, Department of Classics and Ancient History, \\ Durham University, Durham, UK \\ phillip.horky@durham.ac.uk
}

\begin{abstract}
At the beginning of Republic 2 (358e-359b), Plato has Glaucon ascribe a social contract theory to Thrasymachus and 'countless others'. This paper takes Glaucon's description to refer both within the text to Thrasymachus' views, and outside the text to a series of works, most of which have been lost, On Justice or On Law. It examines what is likely to be the earliest surviving work that presents a philosophical defence of law and justice against those who would prefer their opposites, On Excellence by an anonymous author usually referred to as 'Anonymus Iamblichi'; the views on these topics among the Socratics, including Crito, Simon the Cobbler, Aristippus of Cyrene, and Antisthenes; and Socrates' debate with Hippias 'On Justice' in Xenophon's Memorabilia (4.4.5-25). Its main contention is that the 'countless others' referred to by Glaucon points chiefly, but not solely, to the members of the circle of Socrates, who themselves espoused a range of views on justice and law, and their relations.
\end{abstract}

\section{Keywords}

Plato - Socrates - circle of Socrates - justice - law - social contract

\section{Introduction}

At the beginning of book II of Plato's Republic, we witness a second sailing of sorts. Book I has ended aporetically, with no agreed definition of what justice is: Socrates characteristically affirms that the result of the prior discussion is

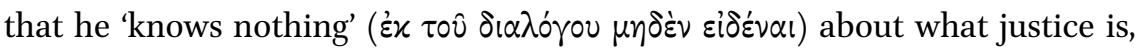


or whether it is one of the virtues, or whether someone who is just is consequently happy or not (Resp. 354b-c). In the light of Thrasymachus' refusal to continue the discussion and Socrates' aporia, things seem bleak for today's discussion of the definition of justice, until Plato's brother Glaucon, 'never one to give up the fight' ( $\left.\dot{\alpha} \varepsilon i \tau \varepsilon \dot{\alpha} \nu \delta \rho \varepsilon \varepsilon^{\prime} \tau \alpha \tau o \varsigma\right),{ }^{1}$ chastises Thrasymachus for giving into Socrates' 'snake-charming' and demands a new start: he says, 'what I'm anxious to hear about is what each of them [sc. justice and injustice] is, and what effect each has the capacity to produce, in and by itself, when it's present in the soul' (Resp. 358b). In order to advance upon this goal, Glaucon takes on the role of dialectical sparring partner, renewing Thrasymachus' praise of the unjust life - not because he believes this, but because he considers this approach fundamental to arriving at a definition of justice, and ultimately to providing an 'encomium' of justice 'for what it is' (Resp. 358d). It is at this point of the dialogue that Plato has his brother present an account of the nature and origins of justice, according to what Thrasymachus and 'countless others'

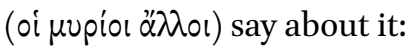

So now you're going to hear about the first subject I said I'd discuss, the nature and origins of justice. What they [sc. Thrasymachus and the countless others] $]^{2}$ say is that doing injustice is naturally a good thing and being a victim of it a bad thing, but that the badness of having it done to one outweighs the goodness of doing it; so that whenever people treat each other unjustly and get a taste of what it's like both to do it and to have it done to them, those who aren't able to choose the one while avoiding the other decide that they'll gain by making a contract - to ban the doing of injustice, and so being the victim of it as well. It's from there, so the story goes, that they start establishing laws, as contracts with each other, calling what is prescribed by the law "lawful" and "just"; and that, they [sc. the countless others] say, is the origin and the essence of justice - something

1 Translations of Plato's Republic are by, or after, C. Rowe, Plato: The Republic (New York: Penguin, 2012).

2 To be sure, there is no evidence that Thrasymachus would accept the social contract solution advanced here. Indeed, at 367 a, Thrasymachus' thesis is also associated with an unnamed 'someone else' ( $\alpha \lambda$ ○ $)$. However, the identity of the 'countless others' remains a question of

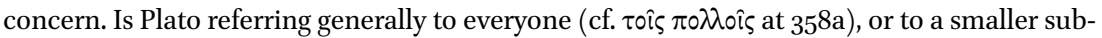

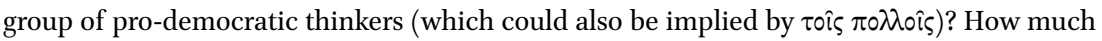
of this is tongue-in-cheek banter with friends and competitors within the Socratic circle? My argument does not exclude the possibility that Plato is referring generally to a widespread view, but rather it proceeds on the principle that being a Socratic need not exclude being pro-democratic, or espousing views that could be associated with more widespread opinions about justice. 
in between what's best for us, acting unjustly and getting away with it, and what's worst of all, being the victim of injustice and being powerless to get one's own back. Being in the middle like this, between the two things, what's "just" is something a person is content to live with, not because it's good, but because it makes up for one's lack of strength to do injustice; anyone who can do it, they say, and is truly a man, wouldn't ever make this contract, "not to do or to be the victim of injustice," with anybody at all - he'd be crazy to do any such thing. So this, Socrates, or something like it, is the nature of justice, as the theory goes, and this is the sort of origin it has.

Resp. $2.358 \mathrm{e} 2-359 \mathrm{~b} 7$

Now this passage is justly famous for presenting what is sometimes taken to be one of the first, if not the first, social contract theory in the Ancient Greek world. The passages offers up an aetiology and an archaeology of justice, positing its 'nature' ( $\varphi \dot{v} \sigma \varsigma)$ and 'natural origin' ( $\xi \xi \hat{\omega} \nu \pi \dot{\varepsilon} \varphi v \kappa \varepsilon)$ : its nature is intermediary $(\mu \varepsilon \tau \alpha \xi \dot{\xi} ; \dot{\varepsilon} \nu \mu \varepsilon \dot{\varepsilon} \sigma \omega)^{3}$ between what's best and what's worst for us, and its natural origin arises from the cycle of committing and receiving injustices, which pro-

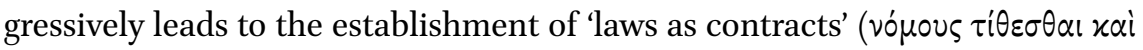

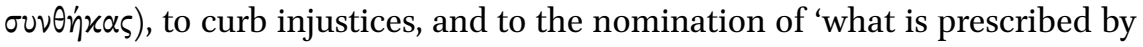

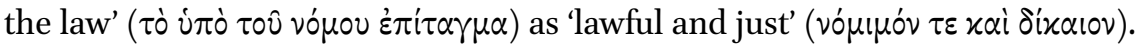
Hence, the conclusion of this generative process is the final association of law with justice, a crucial association that makes possible the grounding of the legal processes in society in the justice guaranteed by nature.

Because Glaucon offers this position up dialectically, it functions here effectively as what Aristotle would call an endoxon, a reputable opinion that can be advanced in order to pursue the question under investigation; hence, for the purposes of Plato's dialogue, it plays an important role in resetting the debate concerning the identity of justice by providing a springboard to further possibilities to be discussed at least until the 4 th book, and then again in the final books, of the Republic. There is, however, another aspect that this passage presents, which helps us to think about the origins of Plato's own dialogue

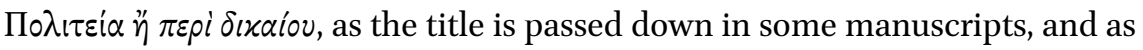
it was known to the editor and arranger of Plato's works, Thrasyllus. ${ }^{4}$ For, by

3 J. Annas, Virtue and Law in Plato and Beyond (Oxford: Oxford University Press), p. 11, refers to it as a 'compromise'.

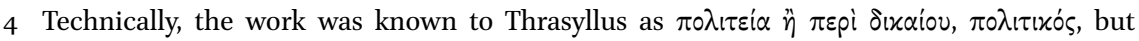
the eponym $\pi 0 \lambda i \tau i x o ́ s$ need not indicate what Thrasyllus himself thought it was entitled. Generally, on the various attested titles of the work we know to be Plato's Republic, see 
pointing beyond the current discussion with Thrasymachus and outside the

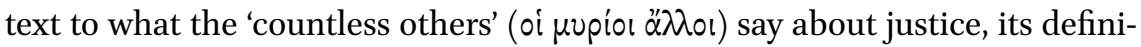
tion and its origins, Glaucon raises the possibility for historians of philosophy that there were works devoted specifically to the topic Пвpi $\delta$ ixaiov, and which offered some room for debate about justice, what it is, and whether it is better to adhere to justice or injustice.

This paper will take its impetus from Glaucon's description of the views of 'countless others' and seek to develop an account of works, or discrete sections

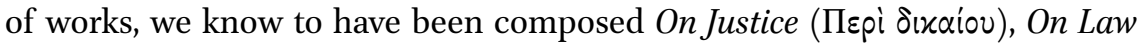

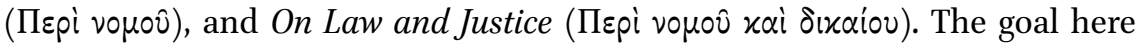
is to identify some common traits shared by texts or sections of works that ascribe to account for these topics in a philosophical way, and which might perhaps point to the existence of a genre of works On Justice, On Law, and On Law and Justice. This study will be confined to a 5o-year period, from the end of the $5^{\text {th }}$ century $\mathrm{BCE}$, from what is likely to be the earliest surviving work that presents a philosophical defence of law and justice against those

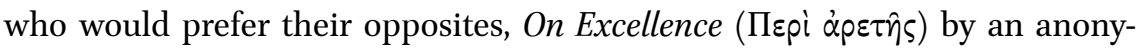
mous author usually referred to as 'Anonymus Iamblichi', to the middle of the 4th century вСЕ, when we can, with some plausibility, assign a terminus ante quem for Xenophon's Memorabilia. Along the way this paper will discuss the treatment of law and justice from what little we can extract of the Socratics Crito, Simon the Cobbler, Aristippus of Cyrene, and Antisthenes, whose com-

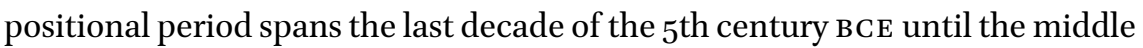
of the 4 th century вСЕ. In seeking to develop a sufficient context for the production of more well-known dialogues and treatises in Plato's Academy and Aristotle's Lyceum, and because other contributions to this special issue of Polis discuss the writings especially of Plato on these topics, this paper will only mention these works by the way. ${ }^{5}$

Anonymus Iamblichi (ca. 400 BCE)

The earliest surviving extended philosophical theorization of law and justice is likely to be a fragmentary text that has come down to us under the name

H. Tarrant, 'Plato's Republics', PLATO: The electronic Journal of the International Plato Society 12 (2012).

5 It is worth noting that much work remains to be done, for example, to unpack the relation-

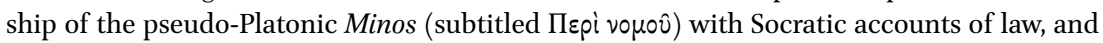

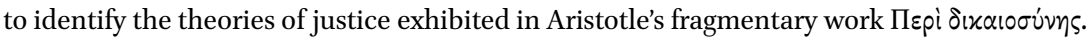


Anonymus Iamblichi (or, the "anonymous author/text from Iamblichus"). For reasons that have been developed elsewhere, I believe the work to have been

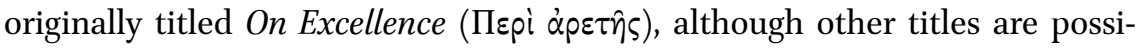

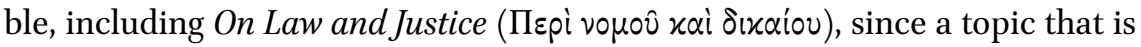
treated extensively in Fragments $6-8$ of the work. ${ }^{6}$ Most scholars agree that this text was written around the end of the $5^{\text {th }}$ century or beginning of the 4th century BCE, and authorship is sadly unknown. ${ }^{7}$ Scholarship has tended to focus on the connections between the thought of Anonymus Iamblichi and the Sophists, especially Protagoras of Abdera; ${ }^{8}$ and more recent attempts to track this treatise's influences and intellectual interlocutors has pointed to Democritus of Abdera. ${ }^{9}$ This paper, however, will seek to place this text within the Socratic milieu, a project that has almost never been undertaken in the scholarship. For, as we will see, On Excellence shows many points of connection with Glaucon's brief summary in Republic II of what the 'countless others' (oi $\mu v p i o r \alpha \lambda$ ol) think about the social contract and the origins and essence of law and justice (as against what Thrasymachus has proposed). ${ }^{10}$

A general summary the argumentative progression to the topic of law and justice helps to situate the content. Fragments 1 and 2 of Anonymus Iamblichi's

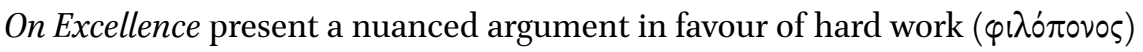

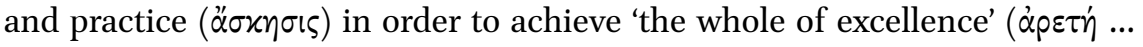
$\sigma \dot{u} \mu \pi \alpha \sigma \alpha)$, which is arguably underpinned by its three parts ( $\mu \dot{\varepsilon} \rho \circ \varsigma \tau \iota \alpha \dot{\tau} \tau \hat{\eta} \varsigma)$ : wisdom $\left(\sigma \circ \varphi \varphi^{\prime} \alpha\right)$, courage $(\dot{\alpha} \nu \delta \rho \varepsilon i \alpha)$, and eloquence $\left(\varepsilon \dot{\gamma} \gamma \lambda \omega \sigma \sigma^{i} \alpha\right) .{ }^{11}$ If one works hard at achieving excellence, whether as a whole or in its parts, she will eventually obtain a good reputation, which in turn engenders, and is further engendered by, trust, and which acts as a preventative to envy, the root of all interpersonal

6 P.S. Horky, 'Anonymus Iamblichi, On Excellence (Peri Aretēs): A Lost Defense of Democracy', in D. Wolfsdorf (ed.), Early Greek Ethics (Oxford: Oxford University Press, 2020), pp. 262-92, at pp. 270-73.

$7 \quad$ For a recent analysis of the question of authorship and the title, see Horky, 'Anonymus Iamblichi', pp. 262-63. Specifically on the title, though, it is worth mentioning here that the topics of law and justice are only treated in Fragments 3 (very briefly), 6, and 8.

Cf. M. Bonazzi, The Sophists, (Cambridge: Cambridge University Press, 2020), p. 3; A. Ciriaci, L'Anonimo di Giamblico: Saggio critico e analisi dei frammenti (Naples: Bibliopolis, 2011), p. 196; D. Musti and M. Mari, Anonimo di Giamblico, La pace e il benessere: Idee sull' economia, la società, la morale (Milan: Biblioteca Universale Rizzoli 2003), pp. 101-3.

9 Horky, 'Anonymus Iamblichi', pp. 272-77.

10 For a nuanced account of the relationship between Plato and Thrasymachus, see D. El Murr, 'Platon contre (et avec) Thrasymaque', in B. Collette-Dučić, M.-A. Gavray, J.-M. Narbonne (eds), L'Esprit critique dans l'Antiquité, Vol. I. Critique et licence dans la Grèce antique (Paris: Les Belles Lettres, 2019), pp. 343-64.

11 For a more comprehensive analysis of Fragments 1 and 2, including the problem of the

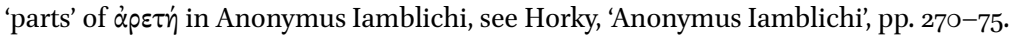


and social discord. Hard work and practice are crucial to achieving trust, and there are no short cuts to a truly good reputation. In Fragment 3, Anonymus Iamblichi considers the situation that occurs once someone has successfully attained excellence and its parts: once these have been brought to perfection,

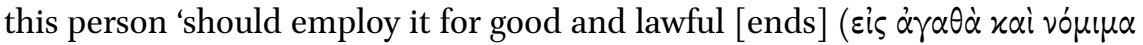

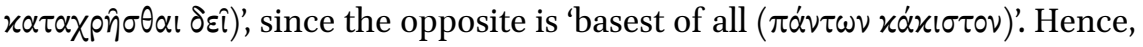
Fragment 3 sees the introduction of the notion of what is of 'lawful' ( $\left.\nu \delta^{\mu} \mu \mu \alpha\right)$ to the text's exhortation to attain excellence ( $\left.\dot{\alpha} \rho \varepsilon \tau \eta^{\prime}\right)$ and its sundry parts. In order to achieve these good and lawful ends, so the author argues, the practitioner of

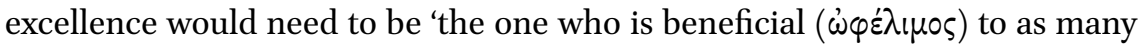
people as possible', a clear indication that Anonymus Iamblichi ascribes to a sort of euergetism - not the sort of monetary euergetism, which sounds nice but will perpetuate cycles of debt, but rather something else:

In sum, how could someone be a beneficiary of humans - not by distributing money, but in some other way - and do these things not with baseness, but with excellence? This will be so in the following way: if he acts in support of laws and justice. For this is what establishes and binds together cities and human beings.

DK $89=98.5^{-12}$ PISTELLI $^{12}$

At this point of the argument, Anonymus Iamblichi would appear to accept the sort of commonplace assumption mentioned by Glaucon in Republic II, namely, that there is a strong relationship between laws and justice in stable human societies, and that these combined are, in Anonymus Iamblichi's words, 'what establishes and binds together cities and human beings' ( $\tau \dot{\alpha} \varsigma \tau \varepsilon$

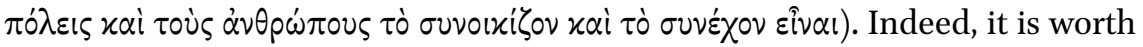
noting here that, among Athenian orators of the late 5th century BCE and onwards, law and justice were intrinsically linked. Based on analysis of several passages of Antiphon, Isaeus, Lysias, Aeschines, and Demosthenes, Mirko Canevaro has followed Edward Harris in arguing that, in democratic Athens, 'the discourses ... of law and justice are one and the same.13 The passages

12 References to Anonymus in this paper combine specification of section(s) in Diels-Kranz (DK89) with page and line numbers from H. Pistelli, Iamblichi Protrepticus. Ad fidem codicis florentini (Leipzig: Teubner, 1888), which allow for more precision. Translation of Anonymus Iamblichi's text is from Horky, 'Anonymus Iamblichi', (but in consideration of alternative readings proposed in A. Laks and G. Most, Early Greek Philosophy, (Cambridge, MA: Harvard University Press, 2016)).

13 M. Canevaro, 'Law and Justice', in G. Martin (ed.), The Oxford Handbook of Demosthenes (Oxford: Oxford University Press), pp. 73-85, at p. 74: 'In fact, far from being a standard 
mentioned by Canevaro and Harris appear to be programmatic and are relatively indistinct: ${ }^{14}$ they demonstrate that correlative appeals to law and justice are rhetorically effective within the confines of the Athenian court in the $5^{\text {th }}$ and 4th centuries BCE, and this success would appear to be a function of Athenian democratic practices, such as the Oath of the Archons, which, according to the author of the Aristotelian Constitution of the Athenians (55.5), required newly selected archons to 'swear that they will exercise their office

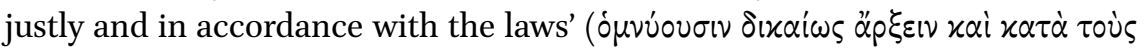
vónovs). Still, these instances of appeal to law and justice in the same breath, many though they are among the orators, are a far cry from the elaborate and directed defence of law and justice found in Anonymus Iamblichi, which is part and parcel of a broader philosophical discussion of and exhortation to public excellence ( $\dot{\alpha} \rho \varepsilon \tau \hat{)})$ we find in Anonymus Iamblichi, whose ideas share not only with the theories coming out of Abdera in the late 5th century BCE (Protagoras and Democritus), but also with a native Athenian morality that traces back to Solon. ${ }^{15}$

For the moment, Anonymus Iamblichi leaves aside this issue and moves forward in Fragments 4 and 5 to discuss the disastrous psychological effects that attend excessive desire for things, including the continuation of one's own life, money, and political contests, in contrast to the eternal immortality that is conferred upon those who achieve renown properly, with excellence. ${ }^{16}$ Instead of aiming for greed, so Anonymus Iamblichi argues in Fragment 6, one should strive to obey and defend the laws, and live as just a life as possible:

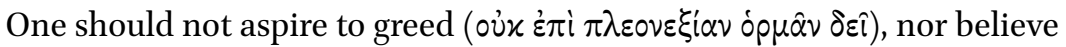

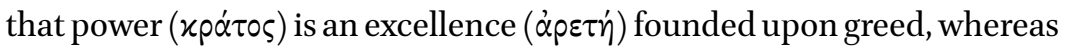
obedience to the laws ( $\tau \hat{\omega} \nu$ vó $\mu \omega \nu$ i $\pi \alpha \kappa \circ \dot{\varepsilon} \varepsilon v)$ is cowardice; for this very

of judgement alternative to the laws, justice is always mentioned by the orators virtually as a synonym of lawfulness. A good example is [Demosthenes] 43.52, where the speaker states: "This is what the law states, and this is what is just" (also e.g. 43.34, 6o, 84; 46.18; (Arist. Ath. Pol. 55.5)). Accordingly, the discourses of law and of justice in the orators are one and the same.' Also see E.M. Harris, The Rule of Law in Action in Democratic Athens (Oxford: Oxford University Press, 2013), pp. 111-14, who lists evidence from Aeschines (3.199-200), Antiphon (5.85), Isaeus (2.47, 4.31, 6.65, 8.46, 9.35, 11.18, 11.35), and Lysias (9.19, 14.22, 14.42, 14.47).

14 With one exception: Demosthenes, Oration 25: Against Aristogeiton 1.15-17 (326/5 BCE).

15 On Protagoras and Democritus in relation to Anonymus Iamblichi, see Horky, 'Anonymus Iamblichi', pp. 272-76. Cf. Solon Fr. 15 West: 'many base men are wealthy, and many good men poor; / but we will not trade their wealth for excellence ( $\dot{\alpha} \rho \varepsilon \tau \dot{\eta})$, since this is always secure, / while one man holds his money, now another.'

16 Again, see my more comprehensive discussion at Horky, 'Anonymus Iamblichi', pp. 279-81. 


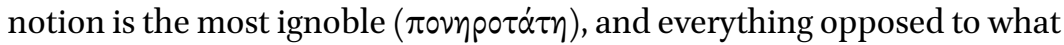
is good arises out of it, viz. baseness and harm. For if humans have been born naturally ( $\dot{\varepsilon} \varphi \dot{v} \sigma \alpha \nu)$ incapable of surviving alone ( $\dot{\alpha} \delta \dot{v} v \alpha \tau 0 l \varkappa \alpha \theta^{\prime} \dot{\varepsilon} v \alpha$ $\zeta \hat{\eta} v)$, formed associations with one another under the compulsion of

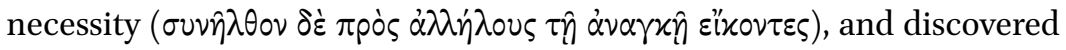

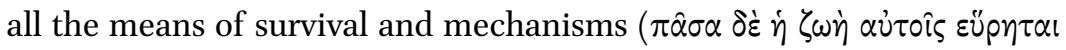
xai $\tau \dot{\alpha} \tau \varepsilon \chi \nu \eta \dot{\mu} \mu \alpha \alpha$ ) for achieving it; and if it was not possible to exist with one another and to pass their lives in a state of lack of respect of law (avopia) (for their losses would be greater in this state than if they were to be alone) - by reason of these necessities, then, law and justice rule

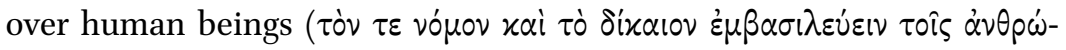
$\pi \circ \varsigma)$ and can in no way be displaced. For these [sc. law and justice] are strongly bound ( $\dot{\varepsilon} v \delta \varepsilon \delta \dot{\varepsilon} \sigma \theta \alpha l)$ in [us] by nature ( $\varphi \dot{v} \sigma \varepsilon l)$. Indeed, if someone were to be born in possession of such a nature as this, invulnerable in his

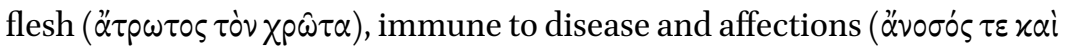

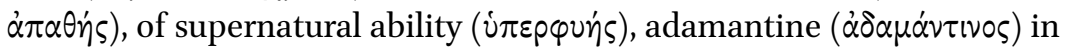
body and life, one might suppose that power founded upon greed would suffice for someone of this sort (for someone like this would have the capacity of going unpunished if he were to refuse to submit to the law); and yet his supposition would be incorrect. For even if there could be someone like this, which could never happen, it would only be by allying himself with the laws and justice, fortifying them, and making use of his strength for their sake, and for the sake of what supports them, that someone like this could ensure his safety; otherwise, he would not last. For all humans would resolve to stand opposed to someone of this nature

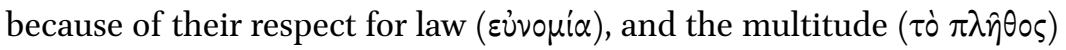
would prevail over and overcome a man of this sort, either through skill

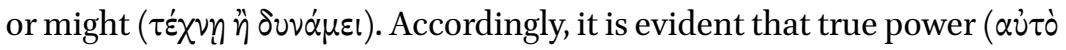

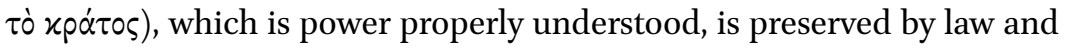
justice. $\left(89=100.5^{-101.6)}\right.$

Here, Anonymus Iamblichi further develops his natural social contract theory by describing it in evolutionary terms ${ }^{17}$ He argues that, if humans were born

17 It is interesting to compare this passage with what is associated with the 'countless others' in the Republic. There are important similarities, but the differences are equally striking: the 'countless others' focus on the gains and losses that most individuals incur in lawless or lawful states, whereas Anonymus Iamblichi is mostly concerned with broader social stability in states that are lawless or lawful, in the context of the pursuit of excellence. To be sure, the concerns over individual happiness and flourishing under various social conditions are explored in Fragments 4 and 5 of Anonymus Iamblichi's text. 
without the capacity to survive or thrive ( $\zeta \hat{\eta} \nu)$ alone; and if therefrom necessity compelled them to form associations; and if therefrom they discovered the technical means to survive and overcome death; and if therefrom they became dissolute and couldn't find a way to get along, as they were in a lawless state ( $\alpha v o \mu(\alpha)$ ); it necessarily follows that law and justice would emerge and come to

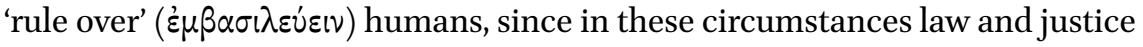
would be shown to be naturally bound to us ( $\dot{\varepsilon} v \delta \varepsilon \delta \dot{\varepsilon} \sigma \theta \alpha \mathrm{l} . . . \varphi v \dot{\sigma} \sigma \varepsilon \mathrm{l})$. It is interesting to note the series of conditionals here: Anonymus Iamblichi would appear to be accepting these propositions as assumptions that cannot be proven; but by accepting them, he is able to arrive at a conclusion that suits his purposes rhetorically. ${ }^{18}$ Similarly, he says, if a rogue Superman were to arrive on the scene, he would be well advised to ally himself with law and justice; for the collective power and ingenuity of the many would eventually overpower any individual's strength of the life and body.

Fragment 7 and the first part of Fragment 8 elaborate a theory of personal and social psychology hinted at earlier in the work and embed it in a praise of the trust $(\pi i \sigma \tau i \zeta)$ that functions as a mechanism for social cohesion. ${ }^{19}$ The last half of Fragment 8 is worth mentioning, however, since it takes up once again the discussion of the Superman, who has now been identified as a tyrant:

And tyranny, an evil of so great a magnitude and character, is a result of nothing other than lack of respect for law ( $\dot{\alpha} v$ pi $\alpha$ ). Some people, who conjecture incorrectly, think that a tyrant comes to power from some other cause, and that humans deprived of their freedom are not themselves the causes of it, but [that they are deprived of their freedom] because they were forced by the tyrant once he has come to power. But their reasoning is incorrect; for whoever believes that a king or tyrant arises out of anything other than a lack of respect for law and greed is a fool. It is whenever all humans turn to baseness ( $\left.x \alpha x^{i} \alpha\right)$ that this happens; for it is impossible for humans to thrive ( $(\hat{\eta} v)$ without laws and justice. So when these two things, law and justice, relinquish the multitude ( $\dot{\varepsilon} \chi \tau 0 \hat{v}$ $\pi \lambda \dot{\eta} \theta 0 u \varsigma \varepsilon \dot{\varepsilon} x(i \pi \eta)$, at that very time the administration and supervision of

18 One is reminded, of course, of Protagoras' speech in Plato's Protagoras. This raises the question of the relationship between Protagoras' own views on the social contract, Plato's presentation of them in the Protagoras, and Anonymus Iamblichi. As M. Bonazzi, 'Ethical and Political Thought in Antiphon's Truth and Concord', in D. Wolfsdorf (ed.), Early Greek Ethics (Oxford: Oxford University Press, 2020), pp. 149-68, at pp. 155-56 argues, such arguments in defence of the social contract guaranteed by laws were challenged by the sophist Antiphon.

19 On trust in Anonymus Iamblichi, see Horky, 'Anonymus Iamblichi', pp. 284-86. 
these things bid a retreat to a single man. For how else could sovereignty devolve to a single man, unless the law, which is beneficial to the multi-

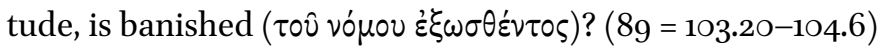

According to Anonymus Iamblichi, those people who think that the tyrant rises up and seizes control of the polis under his own power are fools: it is the people's surrendering of their morality to 'baseness' ( $x_{x i} \alpha$ ), which occurs

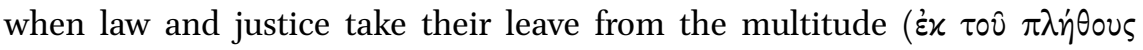
$\dot{\varepsilon} x \lambda i \pi \eta)$ and lawlessness ( $\left.\dot{\alpha} \nu \circ \mu^{\prime} \alpha\right)$ pervades, that leads to the ascendancy of a tyrant. ${ }^{20}$ The process here is described like an ostracism, in which law and justice, which provide fundamental benefits to the people, are banished $(\dot{\xi} \xi \omega \sigma \theta \dot{\varepsilon} \nu \tau \circ)^{21}$ - presumably by the people themselves.

To conclude this part of the paper: when, in the reboot of the debate in

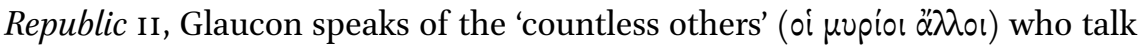
about justice and its origins in the social contract, whereby law and justice are identified as related, he is referring to people such as Anonymus Iamblichi, who, if we are to date his text to 400 BCE, provides the most complete natural social contract theory prior to Plato's works that survives in Greek literature.

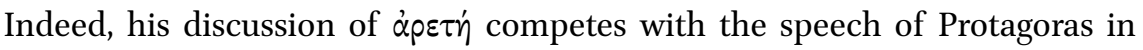
Plato's work by the same name in terms of both creativity and argumentative energy, whilst paying even greater attention to its democratic audience, which might, with the right cues and catch words, be compelled to agree with him. Anonymus Iamblichi's defence of law and justice is robust, supported by imaginative thought experiments whilst remaining sensitive to the sorts of practical issues that faced the everyday Athenian. At this stage, I will turn to what I take to be the most probable milieu within which this treatise (or pamphlet) was produced: the Socratics. It will emerge that Socrates is the common link between such elaborate reconceptualizations of law, justice, and their relations, which makes it probable that when Glaucon refers to the 'countless

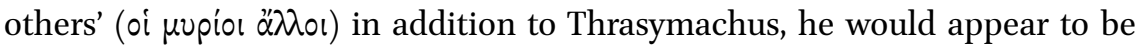
referring to other Socratics; and if this is right, it would compel us to wonder

20 Baseness is discussed earlier in the work at Fragment 3, as the opposite of excellence

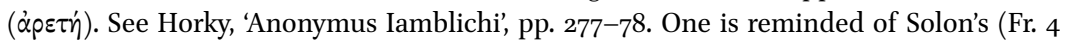
West) paradigmatic description of 'Lawlessness' ( $\Delta v \sigma v 0 \mu$ in), which is ascendancy when the inhabitants of Athens allow themselves to become foolish and ruled by money, and

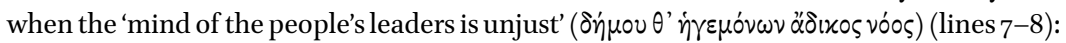

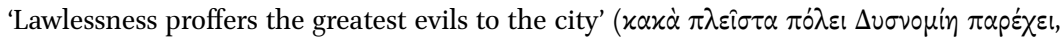

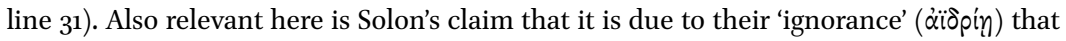
the people become enslaved to a tyrant (Fr. 9 West).

21 Compare with Soph. oc 1296 and 1330. Generally, on exile and ostracism in Athens, see S. Forsdyke, Exile, Ostracism, and Democracy (Princeton: Princeton University Press, 2006), pp. 90-204. 
whether Anonymus Iamblichi too is to be classed as a sort-of eclectic Socratic, who not only draws upon traditions of moral theory and civic ideology in Athens, but also imbues them with Abderite principles concerning personal education and human progress.

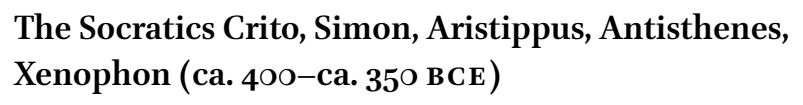

In the previous section we examined the wide-ranging defense of law and justice offered by a late $5^{\text {th }}$ century BCE author, Anonymus Iamblichi, who showed us how a defense of law and justice could be rooted in the advancement of a natural social contract theory. This shows strong connections to the views advanced endoxically by Glaucon in Republic II, and suggests that there might have been a genre, or at least a topical discourse, devoted to studying law, justice, and their relations, prior to and contemporary with Plato's composition of the Republic. Now we will turn to those figures who might be implied as objects of Plato's criticism there, his fellow associates of Socrates, who, as we will see, advanced a range of positions on law, on justice, and on their relations. ${ }^{22}$ The absence of surviving evidence severely hinders our approach, however, as in some cases only hints at what certain members of Socrates' circle believed about these subjects remain. We will take those figures for whom any evidence survives at all and discuss them progressively, from least amount of surviving evidence to most. Hence, we will consider the Socratics Crito of Athens, Simon the Cobbler, Aristippus of Cyrene, Antisthenes of Athens, and Xenophon of Athens.

For two of these figures, Crito and Simon the Cobbler (fl. ca. 40O-ca. 350 в СE?), the scant information we have concerning their views on law and justice come from Diogenes Laertius' lists of their works, all of which have been lost:

So, Crito wrote seventeen dialogues which come down in a single volume, and they are entitled: On the Fact that People are not Good because of Learning ... On Law ...

Diog. Laert. 2.121

\footnotetext{
22 Generally, on the Socratics, see the introduction of George Boys-Stones' and Christopher Rowe's source book, The Circle of Socrates: Readings in the First-Generation Socratics (Indianapolis: Hackett), pp. vii-xiii, and F. Decleva Caizzi, 'Minor Socratics', in M.L. Gill and P. Pellegrin (eds.), A Companion to Ancient Philosophy (Malden, MA: Wiley, 2006).
} 
That is why people call his dialogues 'leathern'. There are thirty-three dialogues which come down in a single volume ... First and second books of On Justice, On Virtue, That It Cannot be Taught ... On Law ...

Diog. Laert. 2.122

While no positive content on their ideas about law and justice can be obtained, it is worth noting a few features: first, Crito allegedly wrote a dialogue On Law, the content of which might be speculatively assumed to relate in some way to Plato's dialogue Crito, which features several points of contact with what has been mentioned above in discussion of Anonymus Iamblichi: concern over the value of public reputation $(44 \mathrm{c}-\mathrm{d} ; 47 \mathrm{a}-48 \mathrm{a})$; the frivolity of clinging to one's life (47e); the relative justice of giving money (48c-d); the status of communal agreements, whether necessary or not $\left(5^{2 \mathrm{~d}}-\mathrm{e}\right)$; and whether it's just or unjust to break the law (45a; 5ob-54d). On Simon the Cobbler, we have even less evidence to work with, although Diogenes tells us that he wrote on several relevant subjects: two dialogues on the topic of justice, one dialogue on law, and a dialogue on the fact that virtue cannot be taught. ${ }^{23}$ This latter position is of course one that could be taken up by various Socratics, and indeed we hear of a dialogue that Crito wrote entitled On the Fact that People are not Good because of Learning. ${ }^{24}$

For his own part, Aristippus of Cyrene (fl. ca. 410-ca. 350 BCE) would appear to have written treatises on various subjects related to our study: a work $O n$ Virtue, and a Protrepticus, which presumably was an exhortation to philosophy, like those of Antisthenes and Aristotle: ${ }^{25}$

According to Sotion in his second book and Panaetius, these are his [sc. Aristippus'] writings: ... On Virtue, Exhortation [to Philosophy] ...

Diog. Laert. 2.85

23 Sadly, the majority of evidence outside of this report of Diogenes concerning Simon's philosophical views comes from the so-called Socratic Epistles, which are a later construction (possibly 3rd century CE) that associates Simon with ideal Cynic behaviours. There, Simon criticizes extravagant living and praises temperance, but nothing survives of his views on law or justice. For an excellent discussion, see R.F. Hock, 'Simon the Shoemaker as an Ideal Cynic', Greek, Roman, and Byzantine Studies 17 (1976), pp. 41-53.

24 Generally, see C. Rowe, 'The Teachability of Aretē among the Socratics', in D. Wolfsdorf (ed.), Early Greek Ethics (Oxford: Oxford University Press, 2020), pp. 629-47, who discusses the views on the teachability of $\alpha \rho \varepsilon \tau \dot{\eta}$ by Euclides, Antisthenes, Xenophon, Aeschines, and Plato.

25 These works only survive in fragments, but the Protreptici of Clement of Alexandria and Iamblichus are extant. I discuss Antisthenes' Protrepticus below. 
Aristippus, a philosopher from Cyrene, said that kingship was as different from tyranny as law from lawlessness and freedom from slavery. Stob., Ecl. 4.8.18

Asked once what advantage philosophers have, he [sc. Aristippus] said, 'If all the laws are taken away, we shall go on living in a similar way'.

Diog. Laert. 2.68

We learn from this meagre evidence two things: that Aristippus saw law as opposed to lawlessness but analogous to kingship and freedom; and that, in a situation where law were to be no longer operative, the philosopher would not change his approach to his life. We are left to infer whether this is because the philosopher is above the law and need not heed it, or whether laws are simply immaterial to the philosopher's integrity, independence, and self-determination. ${ }^{26}$ Indeed, we can only speculate about the contents of Aristippus' Protrepticus, if that indeed is a separate work, but there is reason to believe it focused on promoting, in the words of Tsouna, 'a primarily philosophical education oriented toward the development of one's personality, the acquisition of right ethical principles, and the cultivation of the sort of wisdom conducive to happiness. ${ }^{27}$ We are firmly in the region of personal ethics, and it is telling that no political works devoted to discussing law or justice are attested for Aristippus. ${ }^{28}$ Furthermore, in none of the above cases of Socratics is it obvious that there is any strong association implied between law and justice, as we find in the social contract described by Glaucon. To borrow from Plato's Crito, when Socrates advances anything approaching an associative explanation of what justice is, he says that it is the same as living well and nobly (48b).

It is with Antisthenes of Athens (fl. ca. 420 BCE-ca. 365 BCE), however, that we see formulations more congenial to what we saw in Glaucon's description of the views of the 'countless others' in Republic II and Anonymus Iamblichi:

26 As V. Tsouna, 'Aristippus of Cyrene', in D. Wolfsdorf (ed.), Early Greek Ethics (Oxford: Oxford University Press, 2020), pp. 380-411, notes (at p. 398), the much-discussed passage from Xenophon's Memorabilia (2.1.1-34) shows Aristippus rejecting the traditional division between ruling and being ruled, in favour of a cosmopolitan life of the perpetual and ubiquitous xenos ('stranger'), guaranteed by a life of freedom (2.1.8-11).

27 Tsouna, 'Aristippus', p. 392. It is possible that when Diogenes Laertius preserves the titles

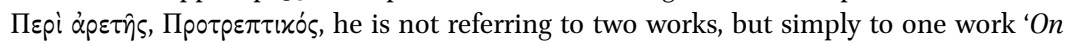
Virtue, a protreptic [writing]'. This is how Antisthenes' work On Justice and Courage is presented by Diogenes Laertius (see below).

28 Aristippus has been thought to evoke a Homeric 'beggar hero' like Odysseus, who lives by travelling around the world without being beholden to political systems (cf. Decleva Caizzi, 'Minor Socratics', p. 132). 
His [sc. Antisthenes'] writings come down in ten volumes ... in the second volume there is On Justice and Courage, an exhortation in three books ... in the third volume there is On Law or Republic, On Law or On Fineness and Justice ...

Diog. Laert. 6.15

Favourite themes with him were the following. He would prove that virtue can be taught; that nobility belongs to none other than the virtuous. And he held virtue to be sufficient in itself to ensure happiness, since it needed nothing else except the strength of a Socrates. And he maintained that virtue is an affair of deeds and does not need a store of words or learning; that the wise man is self-sufficing, for all the goods of others are his; that ill repute is a good thing and much the same as pain; that the wise man will be guided in his public acts not by the established

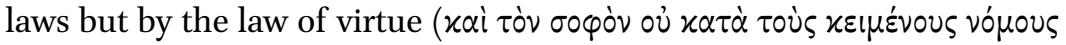
$\pi \circ \lambda \imath \tau \varepsilon \dot{v} \varepsilon \sigma \theta \alpha l, \dot{\alpha} \lambda \lambda \dot{\alpha} x \alpha \tau \dot{\alpha} \tau \dot{\partial} \nu \tau \hat{\eta} \varsigma \dot{\alpha} \rho \varepsilon \tau \hat{\varsigma} \varsigma)$... Diocles records the following sayings of his: To the wise man nothing is foreign or strange. A good man deserves to be loved. Good men are friends. Make allies of men who are at

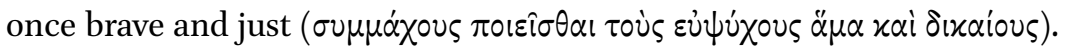
Virtue is a weapon that cannot be taken away. It is better to be with a handful of good men fighting against all the bad, than with hosts of bad men against a handful of good men. Pay attention to your enemies, for they are the first to discover your mistakes. Esteem a just man above a

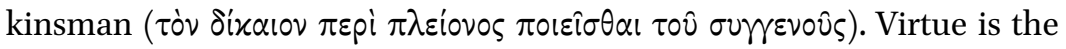
same for women as for men. Good actions are fair and evil actions foul. Count all wickedness foreign and alien. Wisdom is a most sure stronghold which never crumbles away nor is betrayed. Walls of defence must be constructed in our own impregnable reasonings.

Diog. Laert. 6.10-13

This makes it clear that legislation itself is necessarily only about those who are equal, both in birth and in capacity. There is no law for men of outstanding quality; they are themselves the law. Anyone who tried to legislate for them would be ridiculous; they would probably say what Antisthenes had the lions say when the hares harangued them and tried to claim equal rights for all.

Arist. Pol. 2.13.1284a11-17 
[Antisthenes] used to advise the Athenians to pass a vote that donkeys were horses; when they thought that unreasonable, he said, 'Well, generals are made here without their having learned anything, but just by a show of hands'.

Diog. Laert. 6.8

With Antisthenes, we get a better sense of how a Socratic might approach the tangle of issues related to law, justice, and (as with Anonymus Iamblichi)

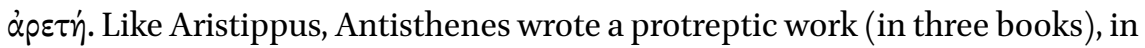
which he exhorted to justice and courage; ${ }^{29}$ it is not implausible that this work contained the 'favourite themes' mentioned by Diogenes Laertius (6.10-11) in the first summary of Antisthenes' views: ${ }^{30}$ that virtue ( $\left.\dot{\alpha} \rho \varepsilon \eta^{\prime}\right)$ can be taught (contrary to Simon the Cobbler and, presumably, Crito); that the virtuous are the only truly noble people; that virtue is evidenced in deeds, not words; that virtue is sufficient for happiness, which is evidenced by the strength of character of Socrates; that the wise man is self-sufficient, since all the goods of other people are his (a curious notion!); and, perhaps most importantly for our analysis, that the wise man is guided not by mere conventional laws, but by the law

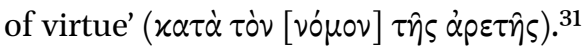

With this last topic, we may see the issues raised by Antisthenes' praise of

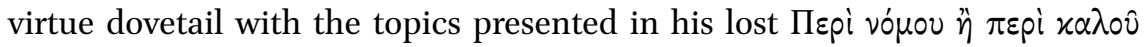
xai swaiov. And, indeed, on the topic of law (vónos), we have the precious testimonium of Aristotle, which would appear to show Antisthenes defending a position like that of Aristippus, whereby the philosopher is above conventional laws, which should not be written with him in mind - note the playful appeal to animals here, and in the testimonium given by Diogenes Laertius (6.8): perhaps Antisthenes followed Socrates in composing Aesopic tales, or at least in using animals as a point of reference for human affairs. ${ }^{32}$ It is clear that such appeals justified Antisthenes' criticisms of democracy ('show of hands'),

29 Cf. Rowe, 'Teachability', pp. 634-35.

30 Decleva Caizzi, 'Minor Socratics', p. 127, refers to this collection of doxai as 'rather disordered', but one wonders whether a list like this, for example, could have been extracted from a Socratic dialogue. After all, evidence from Plato's and Xenophon's Socratic dialogues shows that Socrates did not always argue in an orderly fashion.

31 Cf. S. Prince, 'Antisthenes' Ethics', in D. Wolfsdorf (ed.), Early Greek Ethics (Oxford: Oxford University Press, 2020), pp. 325-6o, at p. 340.

32 One is reminded of Plutarch's philosophical dialogue Gryllus, where Odysseus returns to collect his men from Circe's cave, only to find that his former soldier, now a pig called Gryllus, explains that does not want to be reintegrated into the society of men because humans have less virtue than pigs ( $986 \mathrm{f}-988 \mathrm{f})$. 
or at least arguments that exempted the wise man from democratic legal interference, contrary to what the Crito argues in the personification of the Laws (5ob ff.). The implicit suggestion is that merely human laws and systems of justice do not apply to the бoৎós, who is superior by nature to others - just like the lion is to the hare.

Obviously, such thoughts, especially as they are focused in the character of Socrates, would contribute to the development of Cynic, and, one might imagine, of Stoic ethics. Because of the poor state of the evidence, it is difficult to know how precisely Antisthenes formulated these points (and we should wonder at the ultimate doxographical sources of Diogenes' material, which would almost certainly be contaminated with Stoic ideas). ${ }^{33}$ Be that as it may, it's clear that Antisthenes treated both the subjects of law and justice in his works, and it is possible that he, like Iamblichus many centuries later (and probably

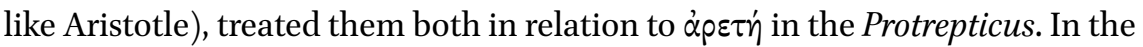
case of one Socratic, however, we have an explicit account of the purported relationship between law and justice, and that figure is Xenophon, to whom we now turn.

Xenophon's Memorabilia was almost certainly written after Plato's Republic (it can be dated to after the battle of Leuctra in $371 \mathrm{BCE}$ ), which is interesting for a variety of reasons: among others, it demonstrates how a Socratic might have sought to rescue the popular image of Socrates from the powerful but almost assuredly deeply biased perspective offered by Plato - especially in a work like the Republic. No less the case on the topic of justice and its relationship to law, which, in the aftermath of Plato's Republic, must have offered ample opportunity for disagreement, especially if the contents of the Republic were to be taken as an expression of the views not of Plato, but of Socrates (as, for example, Aristotle may have taken them to be). ${ }^{34}$ Near the end of the Memorabilia, Xenophon advances his own version of Socrates' debate concerning justice and its definition, in a selection running from IV.4.5-25, effectively

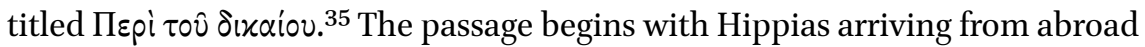

33 Diocles of Magnesia, who lived in the 2nd or 1st century все, is quoted by Diogenes Laertius 19 times and appears to have written a range of works on the history of philosophy (on which, see K. Fleischer, 'Structuring the History of Philosophy: A Comparison between Philodemus and Diogenes Laertius in the Light of New Evidence', Classical Quarterly 69.2 (2020), pp. 684-699, at p. 684 n. 2).

34 Ar. Pol. 2.1, 1261a518; 2.3, 1264b29-1265a14. It is controversial whether we can explicitly identify these views with Socrates the person, Socrates the character in Plato's Republic, or Socrates as known through other literary accounts (e.g. the lost Socratic dialogues, the writings of Xenophon).

35 Generally, on the Xenophontic Socrates' views on law and justice, see D.M. Johnson, 'Xenophon's Socrates on Law and Justice', Ancient Philosophy 23 (2003), pp. 255-81 and 
and hearing Socrates discussing how a range of skilled activities can be taught by teachers, but not justice, for which no teacher is easily found:

Such views frequently found expression in his conversations with different persons; I recollect the substance of one that he [sc. Socrates] had with Hippias of Elis concerning justice. Hippias, who had not been in Athens for a considerable time, found Socrates talking: he was saying that if you want to have a man taught cobbling or building or smithing or riding, you know where to send him to learn the craft; some indeed declare that if you want to train up a horse or an ox in the way he should go, teachers abound. And yet, strangely enough, if you want to learn justice yourself, or to have your son or servant taught it, you know not where to go for a teacher.

Mem 4.4.5

There is some initial friendly banter between the two men, and Hippias, always impressed with his own ability to make novel discoveries whilst maintaining consistency, claims to have discovered a stable definition of justice that cannot be contradicted (i.e. that is superior to convention). ${ }^{36}$ Socrates responds that he would love to hear an account concerning justice that will extirpate civil stasis, in the many ways in which this manifests itself in the polis. But Hippias backs down, unwilling to advance his own account until he has heard Socrates' own 'opinion' (

[Soc.:] 'On my word, you mean to say that you have made a great discovery, if jurymen are to cease from voting different ways, citizens from disputing and litigation, and wrangling about the justice of their claims, cities from quarrelling about their rights and making war; and for my part, I don't see how to tear myself away from you till I have heard about your great discovery'. [Hipp.:] 'But I vow you shall not hear unless you first declare your own opinion about the nature of Justice; for it's enough that you mock at others, questioning and examining everybody, and never willing to render an account yourself or to state an opinion about anything'.

Mem. 4.4.8-9

D. Morrison, 'Xenophon's Socrates on the Just and the Lawful', Ancient Philosophy 15 (1995), pp. 329-47.

36 Compare Hippias' complaints (Pl. Prt. 337c-338b) about law, which is 'tyrant over humans' ( $\tau \dot{v} \rho \alpha \nu \sigma^{\circ} \tau \hat{\omega} \nu \dot{\alpha} \nu \theta \rho \omega \dot{\omega} \pi \omega \nu$ ) and 'commits violence against many things, contrary to nature'. 
Socrates advances upon justice via negativa, enumerating the varieties of injustice, and asserting that justice might be simply abstaining from performing injustices - a proposal that might hold traction over Hippias, who cares much more about evidencing justice in actions rather than in words. But this is unsatisfactory to Hippias, who complains that Socrates is taking his typical stance on things, refusing to advance any positive doctrines concerning a topic. It is at this stage that Socrates advances the proposition that the just is what is lawful:

[Hipp.:] 'Even now, Socrates, you are clearly trying to avoid stating what you think justice to be. You are saying not what the just do, but what they don't do'. [Soc.:] 'Well, I thought that unwillingness to do injustice was sufficient proof of Justice. But, if you don't think so, see whether you like this better: I say that what is lawful is just'. [Hipp.:] 'Do you mean, Socrates, that lawful and just are the same thing?' [Soc.:. 'I do'. [Hipp.:] 'Because I don't see what you mean by lawful or what you mean by just'. [Soc.:] 'Does the expression "laws of a state" convey a meaning to you?' [Hipp.:] 'It does'. [Soc.:] 'And what do you think they are?' [Hipp.:] 'Covenants made by the citizens whereby they have enacted what ought to be done and what ought to be avoided'. [Soc.:] 'Then would not that citizen who acts in accordance with these act lawfully, and he who transgresses them act unlawfully?' [Hipp.] 'Yes, certainly'. [Soc.:] 'And would not he who obeys them do what is just, and he who disobeys them do what is unjust?' [Hipp.:] 'Certainly'. [Soc.:] 'Then would not he who does what is just be just, and he who does what is unjust be unjust?' [Hipp.:] 'Of course'. [Soc.:] 'Consequently he who acts lawfully is just, and he who acts unlawfully is unjust'. 'Laws', said Hippias, 'can hardly be thought of much account, Socrates, or observance of them, seeing that the very people who passed them often reject and amend them'.

Mem. 4.4.11-14

Because they end up basically where they started - that to act justly is the substance of justice, and vice versa for injustice - Hippias exhibits frustration, seeking to challenge Socrates by claiming that laws themselves, and their observance, are not intrinsically valuable, because those individual agents who motivate and agree them later change their minds.

Socrates' solution to this objection is complex, involving analogy with declarations of war by a state, among other comparisons and rhetorical exhortations; but the point that sticks and wins the day involves many of the same terms seen above in Anonymus Iamblichi: 
And again, agreement is considered the greatest blessing for cities: their senates and their best men constantly exhort the citizens to agree, and everywhere in Greece there is a law that the citizens must promise under oath to agree, and everywhere they take this oath. The object, in my opinion, is not that the citizens may vote for the same choruses, not that they may praise the same pipers, not that they may select the same poets, not that they may enjoy the same pleasures, but that they may obey the laws. For those cities whose citizens stick with them prove strongest and enjoy most happiness; but without agreement no city can be made a good city, no house can be made a prosperous house. And how is the individual citizen less likely to incur penalties from the state, and more certain to gain honor than by obeying the laws? How less likely to be defeated in the courts or more certain to win? Whom would anyone rather trust as guardian of his money or sons or daughters? Whom would the whole city think more trustworthy than the man of lawful conduct?

Mem. 4.4.16-17

Given the context we mentioned earlier about the archontic oath that marked the beginning of a magistrate's term of office in Athens, we should not be surprised to see its appearance here. But the emphasis in Socrates' defense of law and justice is placed on a term we haven't explicitly seen in the other Socratics, or in Anonymus Iamblichi, who never uses it: opovoía ('agreement', or 'concord'). Indeed, Socrates here appeals to ópóvola in universal terms, asserting that all Greek city-states - we must here think that he means not just democracies, but oligarchies too - require their citizens to swear an oath to strive for agreement within the polis. ${ }^{37}$ Implicit within Socrates' brief speech is the idea that there is an intrinsic relationship, reflected in the etymological similarity,

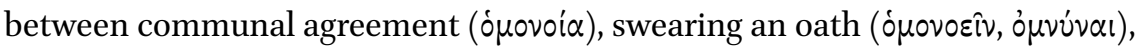
and, I suggest, the law (vópos): in a way, communal agreement essentially is the swearing of an oath to preserve the city's laws. This is not the typical etymo-

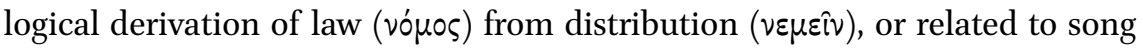
(vómol), versions of which are attested for Plato in the Laws (70ob-c), pseudoArchytas' On Law and Justice (Fr. 4.e Horky \& Johnson), the pseudo-Platonic

37 One wonders how this account would square against Antiphon's work On Agreement

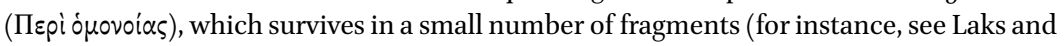
Most, Early Greek Philosophy, 37 D41-63), many of which are too short to integrate into an argument. At any rate, if Antiphon treated law or justice in his work, it is doubtful that he would have advanced a position anything like that of Socrates here. 
Minos (317d-e, 321c-e), and even Cicero (Laws 1.18-19). ${ }^{38}$ As an original formulation, Xenophon's óovoí $\alpha$ presents a sophisticated adaptation of the koina concerning law, justice, and their relations, in Glaucon's speech in Republic II and Anonymous Iamblichi, in a universalizing light that places the emphasis on the oaths that citizens offer up to states, owing to which human happiness is possible.

Remarkably, it is the argument regarding o $\mu 0^{\circ}$ oi $\alpha$, understood as the practice of upholding a sworn oath to the laws, that ultimately convinces Hippias that Socrates' definition of justice as law suffices and is true:

[Soc.:] 'So, Hippias, I declare lawful and just to be the same thing. If you are of the contrary opinion, tell me.' 'Truly, Socrates', answered Hippias, 'I don't think my opinion is contrary to what you have said about justice'.

Mem. 4.4 .18

There would be much more to say with regard to Xenophon's approach to law and justice, including the passage that follows, which features a famous discussion of unwritten and divine laws; but for the purposes of this paper, what has been said is enough to suggest the sorts of arguments Socrates presents there.

\section{$4 \quad$ Conclusions}

Our survey of late $5^{\text {th }}$ and $4^{\text {th }}$ century BCE texts written on the relations

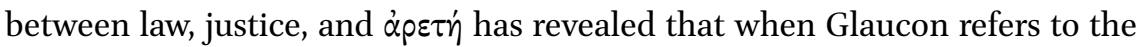
myriad of people who construct natural theories on the essence and origins of justice, grounded in laws established by contract or agreement, he is indeed referring outside the text to a range of possible targets, some of which are Plato's own peers and competitors: the Socratics. The Sophists could be intended targets too: and if we were in possession of the actual writings, say, of Hippias or of Protagoras - and not only of Xenophon's and Plato's potentially unreliable accounts of their views - we might be able to confirm this hypothesis. ${ }^{39}$ Sadly, these texts do not survive to any great extent. What does survive among the

38 See P.S. Horky and M.R. Johnson, 'On Law and Justice attributed to Archytas of Tarentum', in D. Wolfsdorf (ed.), Early Greek Ethics (Oxford: Oxford University Press, 2020), pp. 4559o, at pp. $481-83$.

39 Although, as Dimitri El Murr points out to me, the character Protagoras in Plato's Theaetetus (167a-d) does advance a conventionalist take on justice. But his comments on justice and honour ( $\delta$ ix $\alpha \iota \alpha$ xai $x \alpha \lambda \dot{\alpha})$ are fleetingly brief $(167 \mathrm{c})$, are not the focus of his speech, and have no strict comparanda with the surviving fragments. 
Sophists is inconsistent: on the one side, Gorgias' surviving works and fragments do not attest to the same formulations, interests, or assumptions found in Glaucon's account, or in the other texts analysed today; and while the fragments of Antiphon preserved in the Oxyrhynchus papyri $\left(37 \mathrm{D}_{3} 8 \mathrm{a}-\mathrm{b}\right)$ do treat some of the topics mentioned here, the way they pit law against nature shows little correlation with what Glaucon describes. ${ }^{40}$ For the purposes of contextualizing the endoxic position advanced by Glaucon for the sake of a new start to Plato's dialogue On Justice, the Socratics, along with Anonymus Iamblichi (who just may have been a Socratic himself), provide ample evidence of arguments that locate law and justice - a byword in Athenian democracy - at the heart of questions of ethical behaviour. The truth of the matter is probably not so determinate: it would be an overstatement to say that the Socratics took one line on law, justice, and the good life, and the Sophists another that is wholly contrary; indeed, given what we have seen in this paper, not even the Socratics agree amongst themselves about what this relationship is supposed to be. The usual problem of classifying philosophical arguments, doctrines, principles, and expressions under 'schools' such as 'Socratic' or 'Sophistic', or even 'Platonic' or 'Aristotelian', is as prevalent in the case of early philosophical texts on law and justice as it would be in just about any other subject in classical philosophy. Indeed, the very fact that a variety of positions obtains on a series of related themes within a given 'school', such as the 'Socratics', confirms precisely what we might assume to be the case: Socratic philosophy is best understood not as a commitment to an identifiable set of unquestionable assumptions, but rather as a dedication to collaborative pursuit of answers to an identifiable set of questions amongst a group of like-minded peers. This is the nature of philosophical enquiry - at least with respect to the topics of law and justice, among the students of the most famous know-it-all who himself claimed to know nothing, Socrates. ${ }^{41}$

40 Cf. Bonazzi, 'Antiphon's Truth and Concord', pp. 155-8.

41 My greatest thanks are to Dimitri El Murr, René De Nicolay, and Anthony Bonnemaison, who pressed me on several issues throughout this paper. 